\title{
Histological Characterization of the Oviducal Structures in Guinea Fowl (Numida meleagris)
}

\author{
Yukinori Yoshimura ${ }^{1}$ and Hiroshi Ogawa ${ }^{2}$ \\ ${ }^{1}$ Graduate School for International Development and Cooperation, \\ Hiroshima University, Higashi-Hiroshima 739-8528, Japan \\ ${ }^{2}$ Fuji Zootechnical Station, Tokyo University of Agriculture, \\ Fujinomiya 418-0109, Japan
}

\begin{abstract}
The goal of this study was to determine the mechanism by which thicker eggshell is formed in the guinea fowl as compared with chickens. The structures of the magnum, isthmus, and shell gland as well as the localization of immunoreactive calcium binding protein-D $28 \mathrm{~K}$ (CaBP-D $28 \mathrm{~K}$ ) in the shell gland were compared between the guinea fowl and chickens. The mucosal folds in each oviducal segment consisted of the mucosal epithelium and lamina propria containing tubular glands in both the guinea fowl and chickens. In the magnum the secondary mucosal folds were well developed with forming many large duct-like structures in the lamina propria in the guinea fowl, whereas such structures were not observed in chickens. There was no significant difference in the structures of mucosal tissues in the isthmus between the guinea fowl and chickens. In the shell gland, the distribution of tubular glands in the lamina propria at the bottom region of mucosal folds was denser than that at the apical region of the fold in both the guinea fowl and chickens. In both species, the tubular gland cells of the shell gland contained dense immunoreactive CaBP-D $28 \mathrm{~K}$. The height of the mucosal folds was significantly greater in the shell gland than in the magnum and isthmus in the guinea fowl, whereas it was greatest in the magnum in chickens. The height of the mucosal fold in the shell gland was greater in the guinea fowl than in chickens. These results suggest that structural differences in the oviducal mucosal tissues may be responsible for the formation of thick eggshell in the guinea fowl.
\end{abstract}

(Jpn. Poult. Sci., 35 : 149-156, 1998)

Key words : guinea fowls, eggshell formation, oviducal structure, calcium binding protein-D $28 \mathrm{~K}$

\section{Introduction}

Guinea fowls, the origin of which is west Africa, have some characteristics in their egg production and physiology different from the commercial hens : i.e., (1) their egg shell is markedly thicker (Murayama and KAWABATA, 1978), (2) the yolk : albumin ratio in their eggs is greater (YAMANAKA and FURUKAWA, 1975), and (3) their defense functions against diseases such as Newcastle disease are stronger (W ATANABE and OHMI, 1983; OKAEмE et al., 1988). The thick eggshell of the guinea fowl suggests that they are the excellent resource of birds for the improvement of eggshell quality in poultry. Therefore, it is expected to determine the mechanism by which guinea fowls produce thick eggshell.

Received August 27, 1997 Accepted November 4, 1997

${ }^{1}$ To whom correspondence should be addressed. 
The avian oviduct consists of the infundibulum, magnum, isthmus, shell gland and vagina. The yolk formed in the ovary passes down through the oviduct, and during this process albumin, shell membrane and eggshell are deposited on the yolk in the magnum, isthmus and shell gland, respectively. The time spent by eggs in the magnum, isthmus and shell gland is approximately $3 \mathrm{~h}, 1.5 \mathrm{~h}$ and $20 \mathrm{~h}$, respectively, in chickens (WARren and Scott, 1935 ; Ogawa et al., 1996). Ogawa et al. (1996) who examined the duration of egg formation in the oviduct, found no significant difference in the time spent by eggs within each oviducal segment between the guinea fowl and chickens. To our knowledge, there is no available explanation for the reason why the eggshell of the guinea fowl is thicker than that of chickens. The eggshell calcification occurs by the transport of calcium from plasma, which is absorbed in the intestine and stored in the bone marrow, into the shell gland fluid (Nys, 1993). It is believed that calcium binding protein-D $28 \mathrm{~K}(\mathrm{CaBP}-\mathrm{D} 28 \mathrm{~K})$ contained in the shell gland plays an essential role for the transport of calcium from blood into the shell gland lumen (CoRradino et al., 1993 ; BAR et al., 1996). Therefore, there may be some differences in the structure and CaBP-D $28 \mathrm{~K}$ content between the guinea fowl and chickens.

The goal of this study was to determine the reason why the eggshell of the guinea fowl is thicker than that of chickens. In this study we examined the differences of the oviducal structures between these species, including the structures of magnum, isthmus, and shell gland as well as the localization of CaBP-D $28 \mathrm{~K}$ in the shell gland.

\section{Materials and Methods}

\section{Tissue Preparations}

Guinea fowl hens (610-740 days old, $2.6-3.4 \mathrm{Kg}$ in body weight) and White Leghorn hens (430-540 days old, $1.7-1.8 \mathrm{Kg}$ in body weight) regularly laying 3 eggs or more and 4 eggs or more, respectively, were kept under a light condition of $14 \mathrm{~L}: 10 \mathrm{D}$ and provided with feed and water ad libitum ( $\mathrm{n}=5$ birds each). Guinea fowls were maintained at Fuji Zootechnical Station, Tokyo University of Agriculture. They were killed by decapitation and the oviduct was excised, followed by weighing and fixing in $10 \%$ formalin. Middle parts of the magnum, isthmus and shell gland were dehydrated and embedded in paraffin. Paraffin sections were air-dried on slides. They were stained with hematoxylin and eosin for histology. Some of the sections of the shell gland were immunostained for CaBP-D $28 \mathrm{~K}$. Briefly, sections were incubated with $1 \%$ milk casein in phosphate buffered saline (PBS) to block non-specific binding of the antibodies. They were then incubated with anti-chicken CaBP-D $28 \mathrm{~K}$ raised in mouse (Sigma Chem., St. Louis, MO, USA), which was diluted in PBS containing $0.05 \%$ bovine serum albumin (BSA) at a concentration of $1: 1,000$, for $2 \mathrm{~h}$. After washing with PBS for $15 \mathrm{~min}(5 \mathrm{~min} \times 3$ times), the immunoreaction products of $\mathrm{CaBP}-\mathrm{D} 28 \mathrm{~K}$ were detected by a Vectastain ABC kit for mouse IgG (Vector Lab., Burlingame, CA, USA). Control slides were identically prepared except that the primary antibody (anti-CaBP-D $28 \mathrm{~K}$ antibody) was replaced with normal mouse IgG (Vector Lab., Burlingame, CA, USA).

\section{Observations}

Sections were examined under a light microscope. Height of the mucosal folds, i. 
e. from the bottom border of the lamina propria to the apical point of the fold, was measured by an image analyzer (MacAspect, Mitani Co., Kyoto, Japan). The height $(\mathrm{mm})$ of the folds in one tissue was obtained from an average height of the five highest folds in one section (original height). The hcight was also expressed as the relative height $(\mathrm{mm})$ per $100 \mathrm{~g}$ oviducal weight.

\section{Statistical Analysis}

Significance of difference in the height of mucosal folds among oviducal segments was examined by one-way ANOVA followed by Duncan's multiple t test. The differences in the height of mucosal folds within corresponding segment and the oviducal weights between guinea fowls and chickens were examined by Student's t test. Significance was taken when $p<0.05$.

\section{Results}

The oviduct weight of the guinea fowl was significantly smaller than that of chickens (guinea fowls, $56.9 \pm 2.9 \mathrm{~g}$; chickens, $68.4 \pm 2.5 \mathrm{~g}$; values are mean $\pm \mathrm{SE}, \mathrm{n}=5$
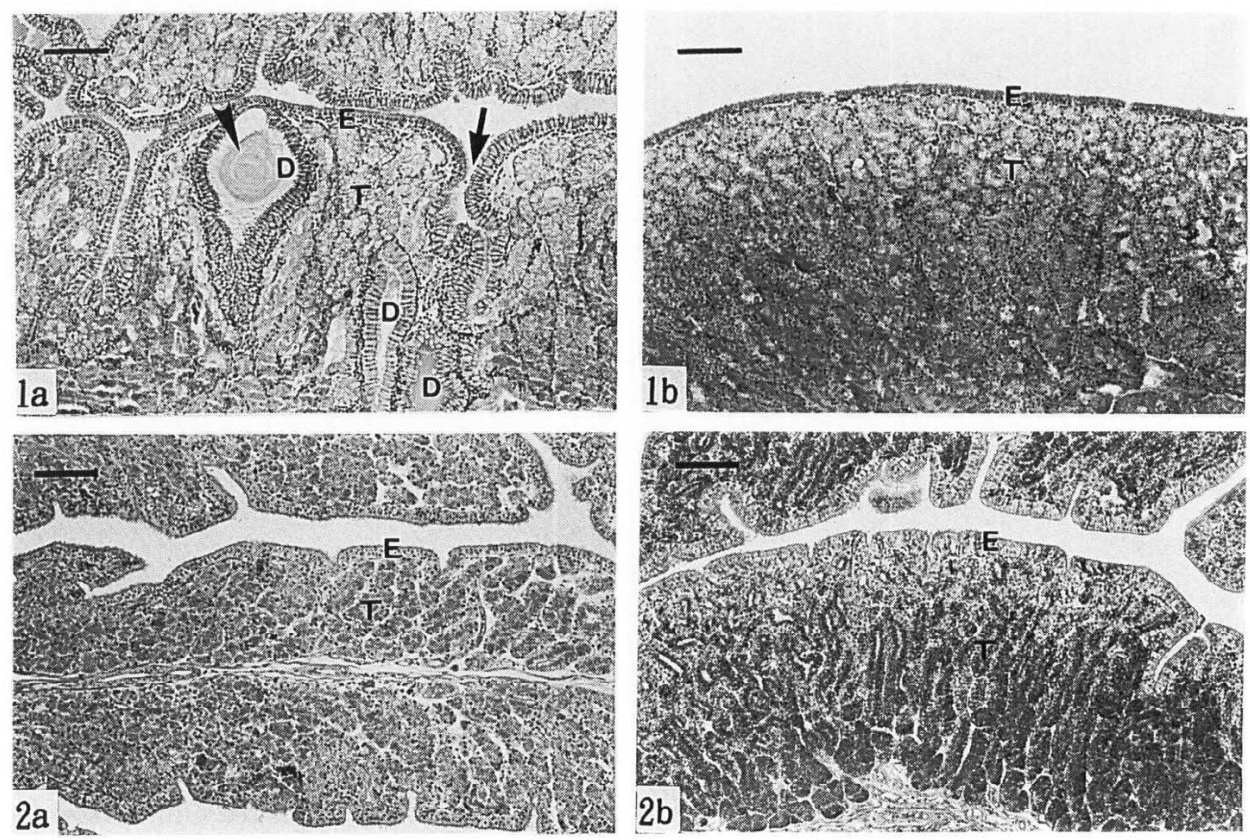

Fig. 1. Sections of the magnum of the guinea fowl (a) and chicken (b). Tubular glands are well developed in the lamina propria in both the guinea fowl and chicken, and the secondary folds (arrow) which form duct-like structures (D) in the lamina propria are observed only in the guinea fowl. Arrow head shows amorphous substance in the lumen of the secondary fold. $\mathrm{E}=$ mucosal epithelium, $\mathrm{T}=$ tubular glands in the lamina propria. Hematoxylin and eosin staining. Scale bar $=100$ $\mu \mathrm{m}$.

Fig. 2. Sections of the isthmus of the guinea fowl (a) and chicken (b). Tubular glands are located in the lamina propria in both the guinea fowl and chicken. $\mathrm{E}=$ mucosal epithelium, $\mathrm{T}=$ tubular glands in the lamina propria. Hematoxylin and eosin staining. Scale bar $-100 \mu \mathrm{m}$. 
birds each) $(p<0.05)$. The wall of the magnum, isthmus and shell gland consisted of the mucosal epithelium, lamina propria, smooth muscle layers and serosa from the inside to the outside in both species.

In both species, the mucosal epithelium of the oviduct was a pseudostratified
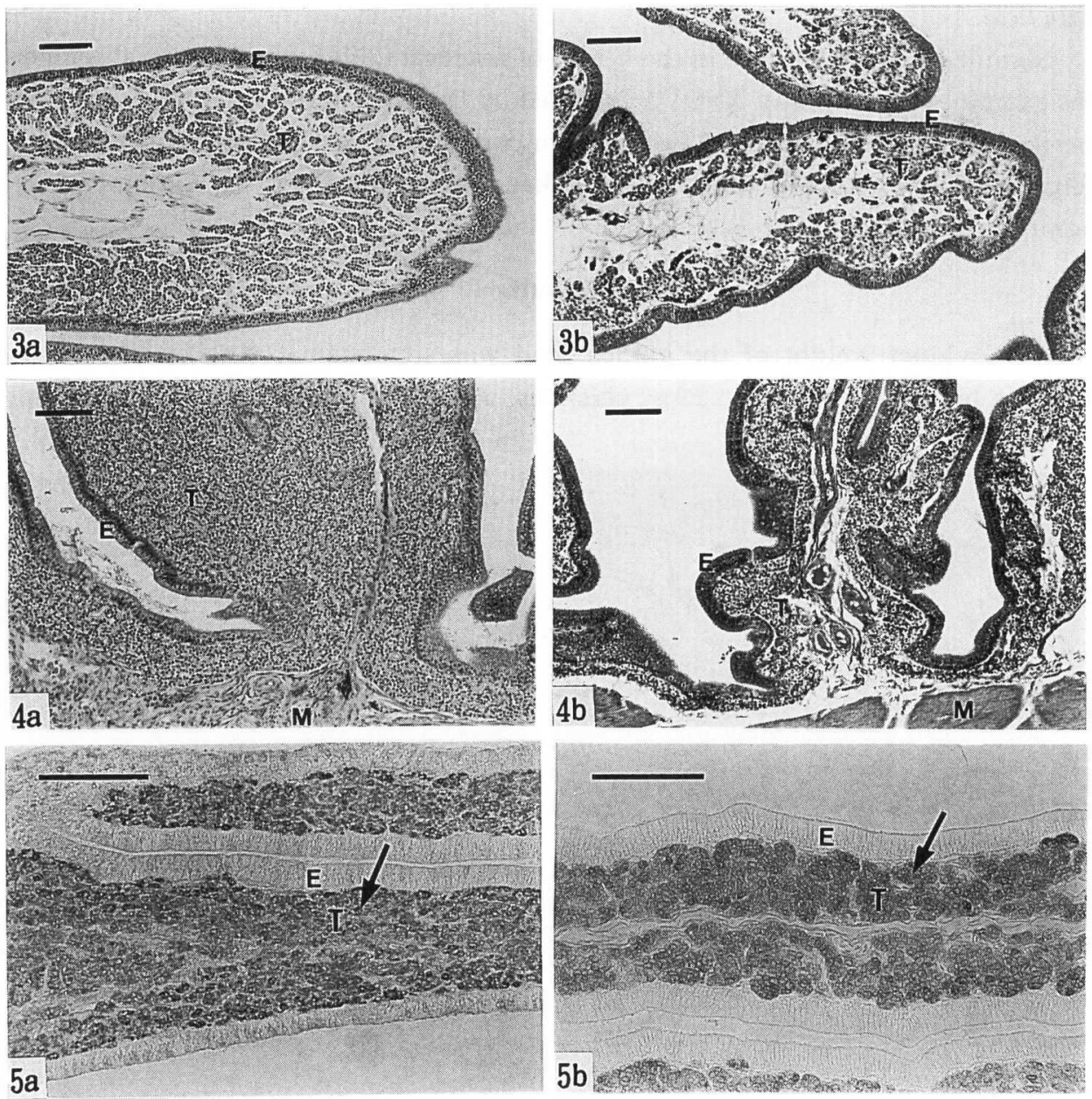

Fig. 3. Sections of the apical region of the shell gland mucosal folds of the guinea fowl (a) and chicken (b). Loose distribution of tubular glands are observed in both the guinea fowl and chicken. $E=$ mucosal epithelium, $T=$ tubular glands in the lamina propria. Hematoxylin and eosin staining. Scale bar $=100 \mu \mathrm{m}$.

Fig. 4. Sections of the bottom region of the shell gland mucosal folds of the guinea fowl (a) and chicken (b). The population of tubular glands is denser as compared with the distribution of them at the apical region of folds (Fig. 3) in the guinea fowl and chicken. $\mathrm{E}=$ mucosal epithelium, $\mathrm{M}=$ smooth muscle layer, $\mathrm{T}=$ tubular glands in the lamina propria. Hematoxylin and eosin staining. Scale bar $=100 \mu \mathrm{m}$.

Fig. 5. Sections of the shell gland of the guinea fowl (a) and chicken (b). immunostained for calcium binding protein $\mathrm{D}-28 \mathrm{~K}$. Note the strong immunoreactions in the tubular glands in both species (arrow). $\mathrm{E}=$ mucosal epithelium, $\mathrm{T}=$ tubular glands in the lamina propria. Scale $b a r=100 \mu \mathrm{m}$. 
epithelium which contained ciliated cells, and the lamina propria in the magnum, isthmus and shell gland contained tubular glands (Figs. 1-4).

In the magnum of the guinea fowl, the secondary mucosal folds were well developed, and they formed large duct-like structures in the lamina propria (Fig. 1a). These duct-like structures were lined by a pseudostratified epithelium which was resembled to the mucosal epithelium, and their lumen was filled with amorphous substances (Fig. 1 a). In chickens, the lamina propria of the magnum did not contain such developed secondary mucosal folds (Fig. $1 \mathrm{~b}$ ). In the isthmus, no difference was observed in the structures of lamina propria between the guinea fowl and chickens (Fig. 2).

In the shell gland of the guinea fowl, the distribution of tubular glands in the lamina propria was markedly dense at the bottom region of mucosal folds, and was loose at the apical region of the folds (Figs. $3 \mathrm{a}$ and $4 \mathrm{a}$ ). Also, in chickens, the density of the tubular glands was denser at the bottom region of the folds than at the apical region of the folds (Figs. $3 \mathrm{~b}$ and $4 \mathrm{~b}$ ). In both guinea fowls and chickens, the tubular glands of shell gland contained dense immunoreactive CaBP-D $28 \mathrm{~K}$ (Fig. 5).
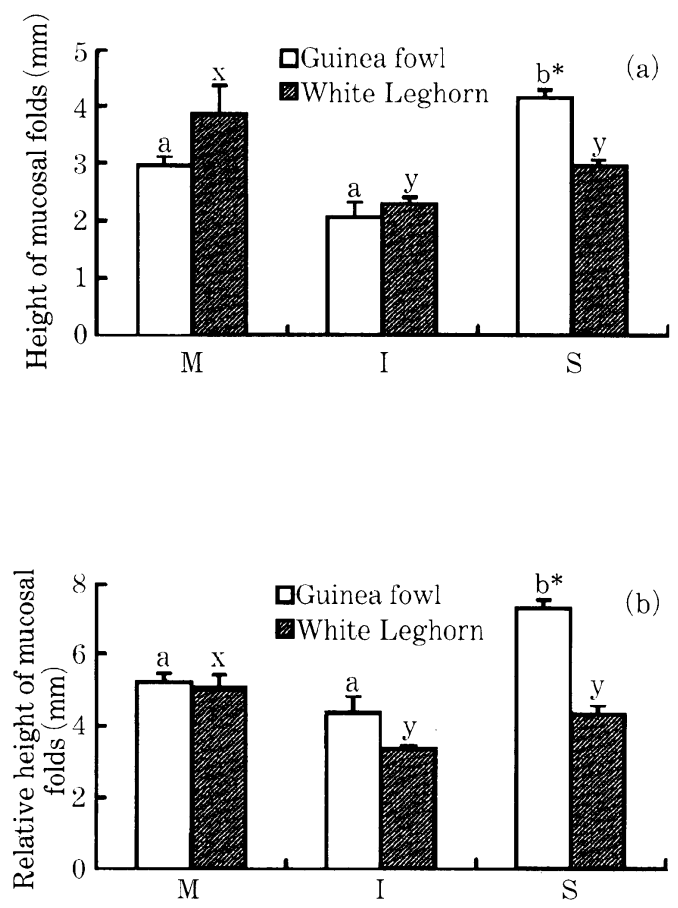

Fig. 6. Height of the mucosal folds in the magnum (M), isthmus (I) and shell gland (S) of guinea fowls and chickens. Upper graph (a) shows the height of the mucosal folds, and the bottom (b) the relative height of the folds per $100 \mathrm{~g}$ weight of oviduct. Bars with different letters are significantly different within each guinea fowl or chicken $(p<0.05)$. Bars with asterisk are significantly different between guinea fowls and chickens $(p<0.05)$. Bars show mean $\pm \mathrm{SE}$ ( $\mathrm{n}=5$ birds each). 
Figure 6 shows the height of mucosal folds in the magnum, isthmus and shell gland of the guinea fowl and chickens. The height of the mucosal folds was significantly greater in the shell gland than in the magnum and isthmus in the guinea fowl $(p<0.05)$, whereas it was greatest in the magnum in chickens $(p<0.05)$. Also, the height of the mucosal folds in the shell gland was significantly greater in the guinea fowl than in chickens $(p<0.05$ ) (Fig. 6 a). Equal patterns of difference in the height of mucosal folds were observed also when the value was expressed as the relative height of mucosal folds per $100 \mathrm{~g}$ oviducal tissue (Fig. $6 \mathrm{~b}$ ).

\section{Discussion}

The significant findings of this study are that (1) in the shell gland of the guinea fowl, as compared with chickens, the mucosal folds were significantly higher and the population of the tubular glands was denser, and (2) the secondary folds were well developed in the lamina propria of the magnum in the guinea fowl but not in chickens.

CaBP-D $28 \mathrm{~K}$ plays an essential role in the transport of calcium for eggshell calcification (Nys, 1993 ; CoRRADINO et al., 1993 ; BAR et al., 1996). The present result confirmed the presence of CaBP-D $28 \mathrm{~K}$ in the tubular glands of the shell gland in chickens as reported by previous workers (LIPPIELlo and WASSERMAN, 1975 ; CoRRADINO et al., 1993). Furthermore, the present results showed that the tubular glands in the shell gland of the guinea fowl also contained CaBP-D $28 \mathrm{~K}$, suggesting that the tubular glands are the site of the calcium transport in the guinea fowl like in chickens. In the shell gland the height of mucosal folds was significantly greater in the guinea fowl compared with chickens. Previous workers failed to determine the mechanism by which the guinea fowl produces eggshell which is significantly thicker than that of chickens. For example, OGAWA et al. (1996) found no significant difference in the length of shell gland and in the time spent by the ovum in the shell gland between the guinea fowl and chickens. We suggest that more developed mucosal folds in the structure, namely the height of the folds, may be the major factor for the formation of thicker eggshell in the guinea fowl.

In the magnum, the secondary folds which formed duct-like structure in the lamina propria was well developed in the guinea fowl but not in chickens, suggesting that the distribution of tubular glands is less in the guinea fowl. Previous reports indicated that the length of magnum was significantly shorter in the guinea fowl than in chickens (OGAwA et al., 1996). The ratio in weight of yolk: albumin was greater in the guinea fowl than in chickens (Yamanaka and Furukawa, 1975). Also, the average weight of eggs was smaller in the guinea fowl than in chickens (MURAKAwA and KAWABATA, 1978). The structural characteristics of the magnum, such as less distribution of tubular glands and the shortness in the length of the duct in the guinea fowl as compared with chickens, may result in a less albumin secretion. Less albumin secretion may be responsible for the greater yolk : albumin ratio and the smaller size of eggs in the guinea fowl. Furthermore, the smaller size of eggs in the guinea fowl may be related in part to the formation of thicker eggshell because the amount of calcium deposition on the egg surface should be greater when an egg is smaller. 
In conclusion, we confirmed that the height of mucosal folds in the shell gland was greater, and the mucosal tissues of the magnum were less developed in the guinea fowl as compared with chickens. These findings suggest that the structural differences in the oviducal mucosal tissues may be responsible for the formation of thick eggshell in the guinea fowl.

\section{Acknowledgments}

The authors thank Mr. Kazuhiro Kaneko, Fuji Zootechnical Station, Tokyo University of Agriculture, for his excellent management of guinea fowls.

\section{References}

Bar, A., E. VAx, W. Hunziker, O. Halevy, and S. Striem (1996) The role of gonadal hormones in gene expression of calbindin ( $\mathrm{Mr} 28,000)$ in the laying hen. General and Comparative Endocrinology, $103: 115-122$.

Corradino, R.A., C.A. Smith, L.P. Krook, and C.S. Fullmer (1993) Tissue-specific regulation of shell gland calbindin D $28 \mathrm{~K}$ biosynthesis by estradiol in precociously matured, vitamin D-depleted chicks. Endocrinology, $132: 193-198$.

LipPIELLO, L. and R.H. Wasserman (1975) Fluorescent antibody localization of the vitamin Ddependent calcium-binding protein in the oviduct of the laying hen. Journal of Histochemistry and Cytochemistry, $23: 111-116$.

Murayama, A. and A. Kawabata (1978) Fundamental studies on the cooking properties of guinea hen's egg. Journal of Home Economics, 29 : 17-21. (in Japanese)

Nys, Y. (1993) Regulation of plasma 1, 25(OH) 2 D 3, of osteocalcin and of intestinal and uterine calbindin in hens. In 'Avian Endocrinology (P.J. SHARP ed.)' pp. 309-320, Journal of Endocrinology Ltd, Bristol.

Ogawa, H., T. Kuwayama and K. TANaka (1996) The timing of ovulation after oviposition and the time spent by the ovum in each portion of oviduct in the Guinea fowl. Japanese Poultry Science, 33 : 118-122.

Okaeme, A.N., A.O. Folorunsho and B.A. FAlayi (1988) An outbreak of newcastle disease in guinea fowl (Numida meleagris meleagris) in Nigeria. Bulletin of Animal Health and Production in Africa, $36: 176-178$.

W ARREN, D.C. and H.M. Scott (1935) The time factor in egg formation. Poultry Science, $14: 195-207$.

Watanabe, T. and H. Oнmi (1983) Susceptibility of guinea fowls to the virus of infections laryngotracheitis and egg-drop syndrome-1976. Journal of Agricultural Science, Tokyo Nogyo Daigaku, 28 : 193-200. (in Japanese)

YAMANAKA, Y. and N. FuRUKAWA (1975) Comparative studies of chemical constituents in the eggs of various birds. Japanese Poultry Science, $12: 114-119$. (in Japanese) 


\title{
ホロホロ鳥卵管の組織学的特徵
}

\author{
吉村幸則 ${ }^{1} \cdot$ 小川 博 ${ }^{2}$ \\ ${ }^{1}$ 広島大学大学院国際協力研究科, 東広島市 739-8528 \\ ${ }^{2}$ 東京農業大学富士畜産農場，富士宮市 418-0109
}

ホロホロ鳥の卵は産卵鶏のあのと比べて著しく厚い卵 款を有する。この機構を明らかにする目的で，ホロホロ 鳥と色色レグホン種の卵管膨大部, 峡部および卵款腺部 の組織構造と卵款腺部のカルシウム結合蛋白 (CaBP-D $28 \mathrm{~K})$ の局在性を比較した. ホロホロ鳥の膨大部では粘 膜二次七ダが粘膜固有層に発達していたが, 産卵彩では これは認められなかった. 峡部は両者の間で構造的差異 を示さなかった. 一方, 粘膜七ダの丈はホロホロ鳥では 卵管 3 部位の中で卵款腺部が最も高く, 産卵彩鳥では膨大 部が最も高かった.さらに, 卵殼腺部の粘膜ヒダの丈は
ホロホロ鳥の方が産卵鶏におけるより有意に高かった。 また，卵款腺部では CaBP-D $28 \mathrm{~K}$ はホロホロ鳥と産卵 鶏のいずれでも管状腺に局在していた。これらのホロホ 口鳥と産卵鶏との間における卵管の構造的差異は両者が 産卵する卵の卵殻の厚さの差と密接に関係するものと考 えられた。

(家离会誌, 35:149-156, 1998) キーワード: ホロホロ鳥, 卵殻形成, 卵管組織構造, 力 ルシウム結合蛋白-D $28 \mathrm{~K}$ 